DOI https://doi.org/10.30525/978-9934-26-180-0-15

\title{
СУБКУЛЬТУРНИЙ КОД ЛІНГВОКУЛЬТУРЕМ АМЕРИКАНСЬКОГО ВІЙСЬКОВОГО СЛЕНГУ
}

\author{
Василенко Д. В. \\ кандидат філологічних наук, \\ доцент кафедри фонетики і практики англійської мови \\ Київський національний лінгвістичний університет
}

Грушецька Т. 0.

студентка 3 курсу навчання

факультету германської філологї

Київький національний лінгвістичний університет

\author{
Отрода I. B. \\ студентка 3 курсу навчання \\ факультету германської філологї \\ Київський національний лінгвістичний університет \\ м. Київ, Украӥна
}

Сленг, нелітературна і некодифікована додаткова лексична система, досліджується лінгвістами, починаючи 3 XVIII століття, 3 метою визначення даного поняття, встановлення складу сленгу, його взаємодії із загальнолітературною мовою, вивчення засобів творення сленгу, виокремлення джерел його поповнення, способів перекладу сленгізмів. Незважаючи на наявність значної кількості наукових праць у галузі сленгу, цей шар лексики залишається явищем, що визначається неоднозначно [1-5]. Вважається, що сленг є різновидом соціолекту, тобто, соціально-маркованої лексики певної суспільної групи, зокрема, професійної, у межах національної мови.

Під військовим сленгом розуміють ненормативну, стилістично знижену і функціонально обмежену мову військовослужбовців, що виконує комунікативну та емоційно-експресивну мовленнєві функції, до складу якої входять військові сленгові лексичні і фразеологічні одиниці. Вони належать до периферії військової лексичної підсистеми.

Низка сучасних лінгвістичних доробок у галузі сленгу присвячені дослідженню сленгізмів у широкому екстралінгвістичному контексті. Відомо, що сленг $є$ динамічною лексичною системою, що характеризується нетривкістю в часі й може взаємодіяти 3 літературною мовою, 
внаслідок чого склад сленгізмів поповнюється новими лексичними та фразеологічними одиницями. Актуальним стає розгляд таких мовних одиниць, які репрезентують знання та уявлення носіїв певної субкультури.

Об'єктом нашого дослідження є взаємодія мови, транслятора культурної інформації, і культури, а предметом вивчення - культурно-марковані американські військові сленгізми. Мета роботи полягає у виокремленні військових лінгвокультурем, визначенні номінативних одиниць, що позначають культурні реалії, шляхів їх творення, описі культурного фону і культурної конотації субстандартної лексики, отриманої шляхом суцільної вибірки і зафіксованої лексикографічними джерелами словниками військових сленгізмів, а також періодичними виданнями та інтернет-сайтами [6-8].

Відомо, що мова не існує поза культурою як «соціально успадкованої сукупності практичних навичок та ідей, що характеризують наш спосіб життя» [9, с. 185]. Як один з видів людської діяльності мова є складовою частиною культури. У якості форми існування мислення і засобу спілкування мова опиняється в одному ряду з культурою. 3 точки зору структури, функціонування, соціокультурний шар, компонент культури, стає частиною мови або фоном їі реального буття. Компонент культури властивий усім рівням мови.

Сукупність лінгвокультурологічної інформації може бути представлена у вигляді лінгвокультурологічного поля, одиницею якого є лінгвокультурема, «діалектична єдність лінгвістичного та екстралінгвістичного (понятійного та предметного) змісту» [10, с. 44-45]. Лінгвокультурема, навідміну від слова, має більш складну структуру. Під планом змісту розуміють мовне значення та культурний смисл. Конотативний смисл лінгвокультуреми «існує до того часу, доки існує ідеологічний контекст, що іiі породжує» [10, с. 52]. Вона $є$ мовно-знаковим носієм культурної інформації, що репрезентована в мовних одиницях, текстах, формах комунікативної поведінки, різних семіотичних системах.

Джерелами лінгвокультурологічної інформації і лінгвокультурем у військовій субстандартній лексиці стають:

1. реалії, пов'язані з життям аборигенів (індіанців) - All-chief-noIndian - «одне керівництво, а підлеглих немає» (вислів індіанця, запрошеного до військової ради, на якій були присутні лише американські oфiuepu): «All Chiefs and no Indians: Leadership in the Team Context» [www.content4reprint.com], Shotgun rider - «стрілець, кулеметник на автомобілі у бойовій готовності до миттєвого відкриття вогню; стрілець гелікоптера по наземним цілям» (в історії освоєння дикого Заходу цей вираз означав людину зі складу поштових диліжансів, яка 
знаходилася зовні із гвинтівкою напоготові, щоб відбити раптовий нanad): «Bo Dudley - Shotgun Rider» [www.johnnybcuz.com], Tee-Pee (The Pentagon) - «Пентагон» (будівля; tее-рее - вігвам індіанців): «The Pentagon has many nicknames, most of them originated in the US Army slang: the "Big House,» «Potomac Palace,» «Puzzle Palace,» «Tee-Pee» [www.brusov.am/docs];

2. фольклор, фольклорні персонажі - Andrew Jackson - «Ендрю Джексон» (емблема військової поліиії-схрещені пістолети, ім'я влучного стрільия), Davy Jones - «Дейві Джоунз» (легендарний дух моря), моряк, що знаходиться у воді без рятувального жилета: «The vibrant colours and sharp quality of our design make you look like you've come straight from the depths of Davy Jones' Locker as part of the skeleton army set to get your share of the ocean's treasure...in barrels» [streetanatomy.com], Davy Jones's locker - «(рундук Дейві Джоунза) морське дно», Gone to Davy Jones «захоронений у морі», Kil Roy - «Кіл Рой, фольклорний персонаж, янки, який встигає випередити усіх»: During World War II, the saying "Kilroy Was Here!» began to appear as graffiti at home and wherever the American military traveled abroad. Eventually the saying, and the cartoon character that often accompanied it, came to represent America's presence throughout the world. Today, it remains a whimsical symbol of the momentous achievements of an entire generation of Americans during the 20th century's darkest hour» [www.ohiohistory.org];

3. географічні назви - Amazon Annie - «280-мм атомна гармата»; Chicago atomizer $=$ Chicago chopper - «автомат-кулемет, автоматична гвинтівка»; Chicago ріапо - «автомат (автомат Томпсона), багатоствольна автоматична зенітна установка, багатоствольний міномет»: «You may not be familiar with the American slang term for playing a piano but for the crew of the USS Hornet CV-8 playing the pianos, as in "Chicago Pianos» was very important. The medium caliber anti-aircraft gun for the USN and the Hornet at the start of the war was the quadruple 1.1-inch automatic cannon, nicknamed «Chicago Pianos» [www.steelnavy.com];

4. музичні інструменти - Army banjo - «мала саперна лопатка»;

5. літературні твори, літературні персонажі - Jeeter - «(другий) лейтенант; груба, невихована людина» (Jeeter Lester - персонаж відомого роману Еркіна Колдуела «Тютюновий шлях»): «Well, when you look at Manchin, you think «Jeeter Lester». You think he might have migrated up from Georgia back in the '30's» [www.guardian.co.uk/commentisfree];

6. кінофільми, мультфільми - Donald Duck - «(каченя Дональд, відомий персонаж мультфільмів Уолта Діснея) пливучий танк / автомобіль з особливим дуплексним приводом (DD-duplex drive)», Donald 
Duck voice - «нечітка вимова в атмосфері, насиченій гелієм», Mickеy Mоияе - «складний прилад; рухомий засіб; учбовий фільм (за різними асоиіачіями з Міккі Маусом, відомим героєм мультфільмів Уолта Диснея)», Smoky the Bear Hat - «капелюх інструктора з муштрового вишколу (ім'я ковбоя із вестернів)», Death Blossom - «тенденція іракських сил безпеки відкривати неприцільний вогонь після невиликого обстрілу з боку супротивника (фраза походить із фільму 1984 року «The Last Starfighter», в якому один корабель перемагає иілу армаду)»: «In The Last Starfighter, the death blossom was a weapon that enabled a single ship to kill off an entire armada. In Iraq, the death blossom is an overreaction-to put it mildly-of Iraq security forces to insurgent fire» [www.good.is/post/mark];

7. відомі люди - Jack Johnson - важка гармата, важкий снаряд (ім'я відомого негритянського боксера).

Засобом втілення культурно-національної специфіки військових лексем слугує образна основа. Лінгвокультуреми позначають військових, зброю, військові дії, обладнання та обмундирування. У більшості випадків дані найменування утворюються вторинною номінацією. Відбувається процес переноса значення за схожістю ознак (метафоричний перенос значення) або процес переноса значення за різними зв'язками між поняттями (метонімічний перенос значення). Асоціативна природа метафори та метонімії приводить до дії такі номінативні механізми, що є властивими певному мовному соціуму і які відбивають його культуру.

В семантиці військових сленгізмів значну роль відіграє конотативний компонент. Такі лексичні одиниці не стільки позначають предмети, поняття, або явища, скільки характеризують їх. Вони також мають значний прагматичний потенціал за рахунок експресивних, емоційних та оцінних елементів значення. Складниками конотативного компонента семантики військових сленгізмів є оцінка, експресивність, емотивність. Оцінка репрезентує ставлення носія мови до позначеного за абсолютною шкалою «добре - нейтрально - погано». Характериними типами оцінки $є$ емоційна, що виходить із почуттів (приємний - неприємний), естетична (прекрасне - потворне) $[11 ; 12]$. За своєю конотацією військові оцінні сленгізми можна розподілити на: 1) негативно-оцінні (Casper - «солдат, який зникає під час виконання роботи, уникає роботи» < Casper - «привід, персонаж мульфільму»); 2) позитивно-оцінні (Rambo stuff - «обмундирування військового» < Raтbо - ім'я персонажа фільму про ветерана В'єтнамської війни, у ролі якого виступив С. Сталлоне).

Отже, за своєю специфікою лінгвокультурний код військової лексики містить як власно мовні властивості, так і екстралінгвістичну ситуацію, певну реалію. В основі творення військових емоційно забарвлених лексем 
$\epsilon$ метафоричний або метонімічний перенос значення. Їх декодування потребує певних фонових знань. Лінгвокультуреми грунтуються на загальному досвіді та рівні знання співрозмовників. Неповна інформативність щодо культури соціуму призводить до створення комунікативного шуму, що викликає перешкоди, які знижують ефективність комунікації і можуть привести до іiі припинення. Вірне сприйняття військових лінгвокультурем не можливе без розуміння реалій, що відбивають особливості військової зброї, умов проходження служби, бойових дій та інші.

Вивчення взаємозв'язку мови і культури військової підмови на основі лексикону $є$ важливим напрямком наукового дослідження, проте не достатнім. Продуктивним напрямком у галузі лінгвокультурології може бути аналіз військового дискурсу.

\section{Література:}

1. Арапов М. В. Сленг. Языкознание. Большой энциклопедический словарь / Гл. ред. В. Н. Ярцева. 2-е изд. Москва: Большая российская энциклопедия, 1998. С. 461.

2. Арнольд И. В. Стилистика современного английского языка. Москва: Просвещение, 1990. С. 208-222.

3. Балабін B. B. Сучасний американський військовий сленг як проблема перекладу: Автореф. дис ... канд. філол. наук: 10.02.16 . Київ. нац. ун-т. К., 2002.19 с.

4. Воробьев В.В. Лингвокультурология (теория и методы). Москва: Изд-во РУДН, 1997. С. 44-52.

5. Гамзюк $M$. . В. Емотивний компонент значення у процесі створення фразеологічних одиниць . Київ: ВЦ КДЛУ, 2000. 256 с.

6. Клименко О. Л. Сленг і його взаємовідносини з літературною мовою - Вісник Запорізького державного університету. Запоріжжя: Запорізьк. нац. ун-т. 1998. № 1. С. 68-70.

7. Селіванова $O$. О. Сучасна лінгвістика: термінологічна енциклопедія. Полтава: Довкілля. Київ, 2006. 716 с.

8. Сепир Э. Язык. Введение в изучение речи. Избранные труды по языкознанию и культурологи . Москва: Прогресс, 1993. С. 185.

9. Судзиловский Г. А. Сленг-что это такое? Английская просторечная военная лексика . Москва: Воениздат, 1973. 182 с.

10. Dickson P. War Slang. American Fighting Words and Phrases from the Civil War to the Gulf War. New York, London, Toronto, Sydney, Tokyo, Singapore, Pocket Books, 1994. 403 p. 
11. Lexicon of Iraq War Lingo: Fightin' Words, October 18, 2007. URL: http:// www.motherjones.com/news/feature/2007/11/iraq-war-glossary.html.

12. War Slang. URL : http://www.globalsecurity.org.

DOI https://doi.org/10.30525/978-9934-26-180-0-16

\title{
МОВНІ ОДИНИЦІ КАТЕГОРІЇ НЕВИЗНАЧЕНОСТІ У ОПОВІДАННІ ЛЮСІ КОЛДУЕЛ $A L L$ THE PEOPLE WERE MEAN AND BAD
}

\begin{abstract}
Давиденко Н. I.
асистент кафедри перекладу та слов'янської філології

Криворізький держсвний педагогічний університет

м. Кривий Ріг, Дніпропетровська область, Украӥна
\end{abstract}

У роботі розглядаємо особливості функціонування у художньому дискурсі одиниць категорії невизначеності різного рівня. Реалізація на мовному рівні такої провідної складової поняттєвого апарату сучасної лінгвістики як принцип невизначеності, який має здатність значно розширювати можливості того, хто говорить в цілях досягнення певного прагматичного ефекту [3, с. 30] привертає увагу все більшої кількості лінгвістів. Мовні одиниці, які належать до досліджуваної категорії, визначаються як слова-обмежувачі та трактуються як лексичні одиниці, що розмивають межі екзістенціонального. Основним аргументом для такого рішення $\epsilon$ здатність подібних мовних засобів здійснювати семантичну корекцію, вносячи до семантики модальне забарвлення приблизності [4, с. 67].

Досліджуване поняття, хоча і не має чіткого визначення у системі мови, лежить в основі походження усіх речей. Останні дослідження наголошують, що визначеність вважається вторинною по відношенню до невизначеності. 3'ясовано, що у процесі зображення дійсності мозком людини, нестабільність та непередбачуваність сучасного життя, корелює 3 інтенсивним ростом у мові форм вираження категорії невизначеності.

Роботу виконано на матеріалі оповідання авторки з Північної Ірландії Люсі Колдуел, All the People Were Mean and Bad (2021 р.), за яке цього року вона отримала національну премію $B B C$. Специфічною рисою оповідання $є$ використання відомого прийому розповіді від другої особи, що робить матеріал особливо цікавим для даного дослідження. У роботі 66 